\title{
The Challenge of Combining High Yields with Environmentally Friendly Bioproducts: A Review on the Compatibility of Pesticides with Microbial Inoculants
}

\author{
Mariana Sanches Santos ${ }^{1,2}$, Thiago Fernandes Rodrigues ${ }^{1,2} \mathbb{D}$, Marco Antonio Nogueira ${ }^{1}(\mathbb{D})$ and \\ Mariangela Hungria 1,2,* \\ 1 Embrapa Soja, C.P. 231, Londrina 86001-970, Brazil; mari_sanches_s@hotmail.com (M.S.S.); \\ thiagoferrodrigues@hotmail.com (T.F.R.); marco.nogueira@embrapa.br (M.A.N.) \\ 2 Department of Biochemistry and Biotechnology, Universidade Estadual de Londrina, C.P. 60001, \\ Londrina 86051-990, Brazil \\ * Correspondence: mariangela.hungria@embrapa.br or biotecnologia.solo@hotmail.com; \\ Tel./Fax: +55-4333716206
}

check for

updates

Citation: Santos, M.S.; Rodrigues, T.F.; Nogueira, M.A.; Hungria, M. The Challenge of Combining High Yields with Environmentally Friendly Bioproducts: A Review on the Compatibility of Pesticides with Microbial Inoculants. Agronomy 2021, 11, 870. https://doi.org/10.3390/ agronomy11050870

Academic Editor: Jerzy Wielbo

Received: 26 March 2021

Accepted: 27 April 2021

Published: 28 April 2021

Publisher's Note: MDPI stays neutral with regard to jurisdictional claims in published maps and institutional affiliations.

Copyright: (c) 2021 by the authors. Licensee MDPI, Basel, Switzerland. This article is an open access article distributed under the terms and conditions of the Creative Commons Attribution (CC BY) license (https:// creativecommons.org/licenses/by/ $4.0 /)$.

\begin{abstract}
Inoculants or biofertilizers aiming to partially or fully replace chemical fertilizers are becoming increasingly important in agriculture, as there is a global perception of the need to increase sustainability. In this review, we discuss some important results of inoculation of a variety of crops with rhizobia and other plant growth-promoting bacteria (PGPB). Important improvements in the quality of the inoculants and on the release of new strains and formulations have been achieved. However, agriculture will continue to demand chemical pesticides, and their low compatibility with inoculants, especially when applied to seeds, represents a major limitation to the success of inoculation. The differences in the compatibility between pesticides and inoculants depend on their active principle, formulation, time of application, and period of contact with living microorganisms; however, in general they have a high impact on cell survival and metabolism, affecting the microbial contribution to plant growth. New strategies to solve the incompatibility between pesticides and inoculants are needed, as those that have been proposed to date are still very modest in terms of demand.
\end{abstract}

Keywords: rhizobia; plant-growth-promoting bacteria; fungicide; insecticide; herbicide; biological nitrogen fixation; inoculation

\section{Introduction}

Technologies and agricultural inputs currently applied for food production are essential for large-scale production and are mandatory to feed a population of more than 7 billion people [1]. Years of research and experiments continually performed into the challenges and technological evolution have resulted in progress in several fields of science. The 1950s was known as the "Green Revolution" period, marked by the intense modernization of agriculture [2,3]. Products including new machines and synthetic fertilizers, with an emphasis on nitrogen $(\mathrm{N})$ fertilizers, pesticides, seeds of better quality, improvements in the water supply systems, breeding and genetic engineering are examples of technologies developed at that time and that have gained prominence in agriculture $[4,5]$.

The main positive result of the Green Revolution was the global increase in food production, thus contributing to the reduction of hunger in the world. However, in the following years, the side-effect of this revolution unfolded [6]. The accumulation of pesticides and chemical fertilizers contributes to the pollution of groundwater and cultivated land, soil degradation, and reduction of biodiversity in different ecosystems [5,7]. Increased deforestation, soil degradation, and emission of polluting gases into the atmosphere have been increasingly observed [8-10]. Despite the undeniable benefits of the Green Revolution, many of the technologies and inputs generated during that period are broadly criticized today. 
Currently, efforts are being made towards the development of new technologies and inputs focused on more sustainable systems.

Contemporary scientists have pointed out that we are living in a "New Green Revolution" whose main characteristic, and which differs from that experienced in the 1950s, is the development of environmentally-friendly technologies and products [3,11-13]. Examples of this new concept include the development of products and techniques such as crop rotation, plant genetic engineering for resistance to pests, diseases, and abiotic stresses such as drought, the use of bio-inputs as activators of soil biota, biopesticides and microbial inoculants, also known as biofertilizers in some countries, with the purpose of partially or fully replacing the use of chemical fertilizers, favoring the growth of plants [14-17].

Although the current movement towards agricultural sustainability has force worldwide, the use of agrochemicals is and will continue to be the reality of most farmers [18]. As such, the common scenario towards improving agricultural sustainability with feasible yields to guarantee food security includes the increasing use of bioproducts, such as microbial inoculants, together with pesticides, which are still indispensable for controlling pests and diseases $[4,5,11,14,17]$. Therefore, the compatibility between inoculants and pesticides must be understood.

In general, pesticides contain molecules that are potentially toxic to living cells. Depending on the specificity, pesticides can cause toxicity to cells of microorganisms, animals, and plants, often resulting in death after contact with the product. In agriculture, they are commonly applied to the seeds, soil, and leaves of plants to prevent or control pests and diseases [7,18-31]. Usually, at least for large commercial crops such as is the case of soybean [Glycine max (L.) Merr.] [11,15,17,20] and maize (Zea mays L.) [26-28] in South America, pesticides and inoculants are added together on the seeds. Thus, it is necessary to verify whether microbial cells in the inoculants are affected by pesticides, impairing the benefits of inoculation.

We should also mention the increasing demand for anticipated inoculation or preinoculation [20], and in the pre-inoculation the most common adoption is to treat seeds with pesticides and inoculants several days before sowing [15,24]. However, the microorganisms are subjected to long-term exposure to pesticides, increasing the pernicious effect on the bacteria and resulting, for example, in decreased nodulation in legumes [21-23], lower N accumulation in grains [24,25], and negatively impacting root development of grasses [26]. These losses may be due to microbial cell death caused by pesticides, as demonstrated in some studies [25-28], in which the longer the contact between bacteria and pesticides, the greater the mortality. Moreover, changes in cell metabolism, such as formation of smaller colonies and decreased nitrogenase activity, have been reported [25].

The world will need more food, and to meet this increased demand, pesticides should continue to be required, at least in a medium term period. However, there is also an increasing demand for environmentally-friendly inputs, including inoculants, to replace chemical fertilizers, and biopesticides to replace chemical pesticides. One major challenge is to make the chemicals and biologicals compatible. In this review, we gathered information on the use of pesticides and inoculants, starting with the history, current situation, and results of studies that investigated the effects of fungicides, insecticides, and herbicides on microbial inoculants.

\section{History and Use of Pesticides}

Studying planting and cultivation practices in ancient times, historians have reported that civilizations were already searching for effective approaches to protect and preserve their food. For millennia, methods such as burning sulfur, using arsenic, growing toxic species together with the crop of interest, and using salts and ashes against weeds were used to protect crops $[29,30]$. In one of the oldest documents, from approximately $1550 \mathrm{BC}$, called the Ebers Papyrus, interesting information about techniques used to eliminate insects from food planting areas has been described [30]. The report describes a mix of mercury and arsenic that was used for pest control [30], and a century later, arsenic was used along 
with honey, especially against ants. In 1867, during a potato beetle [Leptinotarsa decemlineata (Say)] outbreak in Colorado, USA, arsenic was used for pest control [29]. During the 1850s, a vineyard owner from Bordeaux, France, applied a mixture of copper and lime to grapes. Initially, the objective was to keep thieves away from his vineyards, but the wine producer realized that the application resulted in lower incidence of diseases. Notably, this mixture is still used today as a fungicide. Over the years, insecticides derived from plants have been discovered, such as pyrethrins and nicotine, the latter used specially to control aphids [19].

In 1939, Paul Müller discovered dichlorodiphenyltrichloroethane (DDT), which was the first modern pesticide. This product played an important role during World War II when it was broadly used to control diseases transmitted by insects, such as malaria and typhus, ensuring soldiers' health. The discovery of DDT resulted in considerable benefits to agriculture and human health, resulting in Müller being awarded the Nobel Prize in Medicine in 1948. Numerous other cheap and effective synthetic organic pesticides have been developed, contributing to a breakthrough in the market and starting a new era in pest and disease control [19,29-31]. Fungicides such as captan and glyodin, the insecticide malathion, and the herbicide triazine were introduced in the following decades [29].

The use of pesticides increased until 1962 when the development of new products began to slow down because of the first studies and reports on the environmental and health risks associated with the indiscriminate use of pesticides. The book "Silent Spring" (1962), authored by the American scientist Rachel Carson, played an important role in the history of pesticides. In the book, the author discusses the harmful effects caused by the field spraying of several pesticides containing chlorinated hydrocarbons, among them the most important at the time, DDT. The effectiveness of these products is closely related to their stability and persistence in the environment, but they are also able to accumulate in the adipose tissue of some animals, a process known as bioaccumulation, which in some cases results in biomagnification, factors that make these compounds highly dangerous $[19,29,30,32]$. Another important finding was the confirmation of the housefly (Musca domestica, L) resistance to DDT in Sweden only after a few years of application, another negative point for the use of this product [19].

As a result, in 1972, the US Environmental Protection Agency (EPA) banned the use of DDT in the country, and several pesticides were classified as restricted use, for example, endosulfan, dieldrin, and lindane. Organophosphorus and carbamates, which have lower risk, had been suggested as alternatives $[19,29]$. DDT was banned in several other countries and, in 2001; during the Stockholm Convention, 179 nations signed a treaty that agreed to ban 12 persistent organic pollutants (POPs). It is interesting to note that since the 1960s, when both pesticides production and use became strictly regulated, alternative methods for pest and disease control began to be studied, with an emphasis on biological control (BC) $[19,29,30]$ and integrated pest management (IPM) [33]. The principle of IPM is based on understanding population dynamics and using actions compatible with the environment to minimize the incidence of pests. In 1998, Kogan defined IPM as "the intelligent choice and use of control tactics that will produce favorable consequences from an economic, ecological, and sociological point of view." In conclusion, the principle is to use several compatible techniques to keep the pest population at levels below the capacity that causes economic, social, and environmental damage. IPM is currently widely used in crops around the world and is responsible for excellent results like reduced use of chemicals and increase in yields, in addition to other traditional methods such as mechanical and physical control and use of resistant plants, but is not able to fully replace the use of chemical pesticides, which are still used on a large scale [34].

In 1990, the average worldwide use of pesticides by cultivation area was of $1.5 \mathrm{~kg} \mathrm{ha}^{-1}$. Almost 30 years later, this value grew considerably, reaching an average of $2.63 \mathrm{~kg} \mathrm{ha}^{-1}$ in 2018. The continents that applied more pesticides in 2018 were Asia and America, reaching $3.67 \mathrm{~kg} \mathrm{ha}^{-1}$ and $3.52 \mathrm{~kg} \mathrm{ha}^{-1}$, respectively. Europe applied $1.66 \mathrm{~kg} \mathrm{ha}^{-1}$ of pesticides, while in Africa the average application was $0.3 \mathrm{~kg}^{-1}$ [18]. Among Asian countries, China, Japan, and Korea had the highest averages of pesticides per hectare in 2018 , reaching $13.07 \mathrm{~kg} \mathrm{ha}^{-1}$, 
$11.84 \mathrm{~kg} \mathrm{ha}^{-1}$, and $11.73 \mathrm{~kg} \mathrm{ha}^{-1}$ respectively. High rates were also reported in 2018 for South American countries, including Ecuador $\left(25.8 \mathrm{~kg} \mathrm{ha}^{-1}\right)$, Uruguay $\left(8.16 \mathrm{~kg} \mathrm{ha}^{-1}\right)$, Brazil $\left(5.94 \mathrm{~kg} \mathrm{ha}^{-1}\right)$, Chile $\left(5.86 \mathrm{~kg} \mathrm{ha}^{-1}\right)$, and Argentina $\left(4.29 \mathrm{~kg} \mathrm{ha}^{-1}\right)$, while the United States of America (USA) applied an average of $2.54 \mathrm{~kg} \mathrm{ha}^{-1}$ of pesticides in the same year [18].

Each country has its own laws and regulations regarding the production, commercialization, and use of pesticides, designed mainly to protect human and environmental health. Among the actions of regulatory agencies are, for example, limitation of species to which a certain pesticide can be used, the requirement to use protective equipment, and the total prohibition of any product that is proven to be dangerous, which cannot be reliably mitigated [35]. Estimates point out that since 1970, 508 types of active ingredient have been used in the USA, 134 of which were banned, with the majority of the cancelations taking place voluntarily by the manufacturers; only 37 prohibitions came from judicial decisions. The United States is behind other countries with regard to banning pesticides, probably due to deficiencies in the legislation. From the list of pesticides still in use in the United States, 72 of them have been banned in the European Union, 17 in Brazil, and 11 in China [35].

Several studies have been carried out in the past few decades to understand the damage to human health and the environment caused by certain chemical pesticides [36-38]. These studies are very important because they generate information to guarantee food security. However, crop management still requires the application of pesticides to achieve high yields to meet the world 's increasing demand for food. Given this scenario, the indications are of a continuing use of pesticides, but with a trend toward more environmentally friendly formulations, such as the replacement by biological control.

\section{Inoculants or Biofertilizers}

Following the trend of agricultural production and concern about environmental sustainability, an innovative biotechnological product based on living microorganisms capable of making nitrogen available to plants was patented in 1896 and launched in 1898 by the first inoculant producing company, Nitragin, replacing the application of potentially polluting $\mathrm{N}$ fertilizers. The first inoculant contained nitrogen-fixing rhizobia for soybean crop [17,39-41]. Rhizobia are diazotrophic bacteria with an enzymatic apparatus to realize the biological nitrogen fixation (BNF) process, in which atmospheric nitrogen $\left(\mathrm{N}_{2}\right)$ is converted into ammonia $\left(\mathrm{NH}_{3}\right)$ and further to organic compounds that are easily assimilated by plants (Figure 1). Therefore, when diazotrophic microorganisms are associated with specific plants, they supply nitrogen to their host, contributing to their development, and in return receive photosynthates from the host plant for their metabolism [42,43].

Since the first inoculant was launched, a variety of inoculants has been produced, including rhizobia and other plant growth-promoting bacteria (PGPB) [17]. It has been necessary to research on several fronts, including the selection of microorganisms for each plant species [44-49], development of the culture media [50,51], search for inoculant carriers [52-55], development of large-scale production, product distribution logistics, methods of inoculation [56-58], among others. Such studies have been responsible for expanding, diversifying, and improving the quality of inoculants. There are several reports on the contribution of inoculants increasing yields of crops at a low cost and mitigating the environmental impact $[15,17]$.

As the production and commercialization of inoculants have increased, some countries have created laws to standardize, supervise, and guarantee the safety and quality of these bioproducts. In 1954, a microbiology professor at the University of Sydney, Australia, listed basic recommendations for quality control and use of legume inoculants, establishing the first quality control laboratory in the country. The Australian Inoculant Research Group (AIRG) is responsible for quality control. Since 2010, Australian inoculants that meet quality standards have exhibited a trademark called "Green Tick Logo," which certifies that the product contains the correct strain, the number of living cells equal to or above the standard, and the minimum number of contaminating microorganisms [59]. Australian legislation served as a basis for legislation in other countries, such as in Uruguay and Brazil. 
In Brazil, legislation was established in 2004 and updated in 2011 [60-62]. Australia has moved to voluntary participation in the quality control of commercial inoculants, while in other countries such as France and Canada, as well as in many South American countries, participation is mandatory. The third group, including the US, comprises only internal control by the industry $[17,63]$.

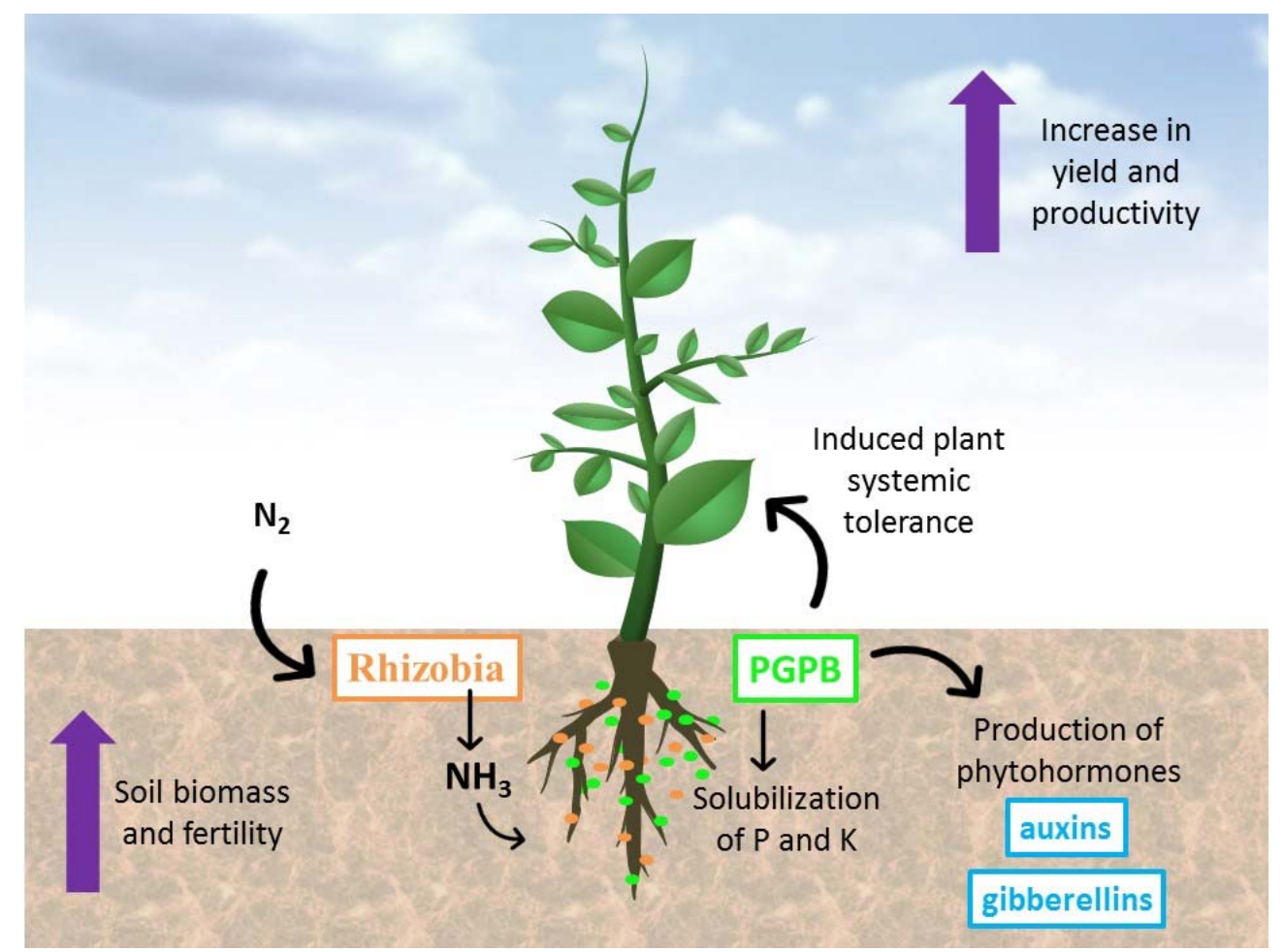

Figure 1. Main benefits of inoculation with rhizobia and plant-growth-promoting bacteria (PGPB). Biological nitrogen fixation (BNF), phosphate (P) and potassium (K) solubilization, phytohormone production (auxins and gibberellins), and induced plant systemic tolerance to abiotic and biotic stresses are represented. As benefits, there are increases in biomass production, yield, and improvement in soil fertility.

Brazilian standards include a list of bacterial strains authorized for inoculation in different plant species, establishing a minimum cell concentration, and the limits for contaminants. Inoculants containing rhizobial species must present $1 \times 10^{9} \mathrm{CFU}$ (colonyforming units) per gram or mL until the expiration date, which must be at least 6 months, but other species may register with lower concentrations [61,62]. The maintenance of cell concentration contributes to achieving the desired performance and ensuring product quality, but it is a challenge for the industry, as several factors can affect cell survival such as temperature, $\mathrm{pH}$, drought, light, and availability of nutrients $[50,51,53,63,64]$.

Soybean inoculation is certainly the most successful example worldwide, with an emphasis in South America. For example, in Brazil, it is well known that inoculation with elite Bradyrhizobium spp. strains fully supplies the plant's demand for nitrogen, avoiding the use of N-fertilizers even with high-yielding genotypes [15,42]. In the 2019/20 crop season, approximately 36 million hectares were cropped with soybean in Brazil, and even though most of the area had been inoculated in previous seasons, about $80 \%$ of the farmers adopted annual inoculation $[65,66]$. Traditionally, soybean in Brazil has been inoculated only with Bradyrhizobium spp. strains [15]; however, in the past five years, co-inoculation of Bradyrhizobium spp. with the PGPB Azospirillum brasilense has been increasingly used, so that in a short period it has been adopted by $25 \%$ of the farmers $[65,66]$. The main trait of the $A$. brasilense strains used for co-inoculation of soybean in Brazil has been recognized as the synthesis of phytohormones $[67,68]$. 
Besides phytohormones synthesis, beneficial properties associated with PGPB include BNF, phosphate and potassium solubilization, production of siderophores, detoxification of heavy metals, induction of plant systemic tolerance to abiotic and biotic stresses, production of hydrolytic enzymes, and production of exopolysaccharides [69-75] (Figure 1). Such properties have been reported in several microorganisms, and the most commonly cited carrying one or more of these properties are Azospirillum spp. [72,76], Pseudomonas spp. [77-79], and Bacillus spp. [80,81], among others [71,82]. With important properties and taking advantage of different microbial processes, the inoculation with mixes of bacteria has gained increased attention $[67,68,82-84]$. Some proposed mixes combine several species [75,82], but one knows that it is difficult to grow and maintain proper concentrations of bacteria with different metabolic needs, In addition, a thorough preliminary study must be carried out so that the chosen species are compatible with each other.

Before being used as a co-inoculant for legumes, PGPB such as A. brasilense has long been used in the inoculation of non-legumes, especially grasses such as maize, wheat (Triticum aestivum L.), and rice (Oryza sativa). Inoculants containing A. brasilense have been commercialized for more than 20 years; since 1996 in Argentina [76], 2002 in Mexico [85], and 2009 in Brazil [17,44,66]. A. brasilense can fix nitrogen, but in much lower quantities than rhizobia, making necessary supplemental $\mathrm{N}$-fertilizer. The possibility of reduction of approximately $25 \%$ of the $\mathrm{N}$-fertilized has been observed when $A$. brasilense is used as an inoculant in maize and this is environmentally and economically important $[44,57,66,86]$. One of the greatest benefits of $A$. brasilense is its ability to produce phytohormones, such as auxins, that stimulate root development [72,87], and gibberellins [87]. In addition, $A$. brasilense can induce plant defense mechanisms under abiotic and biotic stresses $[69,70,72,73]$. Due to excellent results of inoculation with $A$. brasilense in several crops [88], it is expected that this practice will continue to grow in the coming years. In Brazil, in a short period of 10 years, since the first commercial inoculant containing $A$. brasilense was launched, the number of commercialized doses reached 10.5 million in 2020 [66].

Rhizobial inoculants have been traditionally used in pasture-growing legumes, mainly alfalfa (Medica sativa L.) [89]. However, as most pastures worldwide have grasses, the use of other PGPB in important pastures such as brachiarias (Urochloa spp.) has increasingly attracted attention, with results showing improvement in soil fertility, biomass yield, and nutrient content in the forages (Figure 1) [12,90-92]. The inoculation pastures of grasses with PGPB has environmental and economic importance because most of the pastures worldwide are at some stage of degradation [93,94]. By offering better quality fodder to cattle, the pastures can hold a larger number of animals, making saving of other areas from transformation into pastures.

There are different ways to deliver the inoculants to the crops. Seed inoculation is the most common and easy method, as it can be carried out using solid or liquid inoculants. In this process, the inoculant is applied to the surface of the seeds, with or without stickers, which are then shaken so that the product spreads evenly. Other methods of applying liquid inoculants are possible, such as spraying on the soil surface or applying the product in the sowing furrow. Another alternative is leaf spraying, which can be done during certain periods of plant growth. Regardless of the strategy of inoculation, it is extremely important to apply the correct dose of the product, according to the manufacturer's recommendations, as lower or higher cell concentrations may decrease inoculation efficiency $[56,57,67,95]$.

\section{Are Pesticides and Microbial Inoculants Compatible?}

As the benefits of inoculation are closely related to the establishment of a plantmicroorganism interaction, the survival and maintenance of microbial properties are crucial and mandatory. Therefore, the evaluation of microbial survival at the time of inoculation, and of the effectiveness on the inoculated crop are critical. The most common situation in commercial crops is the combination of several products for different purposes, such as soybean seed treatment with microbial inoculants for nitrogen fixation, fertilizers and pesticides for the prevention or treatment of pests and diseases. In many cases, depending 
on the mode of application, one product ends up being exposed to the other, or interacting with one another either on the seeds, propagated material, in the soil, or leaf surface. It is important to know whether the contact of pesticides with microorganisms in the inoculant can affect cell survival and metabolism. Concerns about the compatibility of agrochemicals with microbial inoculants have been raised for decades, and several studies have shown that the impact of chemicals on the inoculant depends on the active ingredient, the presence of other chemical substances that make up the formulation of pesticides, the mechanism of action (systemic or contact), and the method of application. The effects of incompatibility also depend on the bacterial species present in the inoculant, which may have different responses. However, few species have been evaluated for this purpose. The most recurrent ones belong to the genres Rhizobium spp., Bradyrhizobium spp. and Azospirillum sp.

\subsection{Compatibility with Fungicides}

Fungicides are chemical products formulated to prevent the infection of plant tissues by phytopathogenic fungi, and in some cases, capable of extending the control of diseases caused by bacteria and viruses. The control exerted by fungicides can be mediated by killing the pathogen, temporarily inhibiting its germination and growth, or by affecting the production of spores [96]. Over the years, several fungicides have made it to the market; some have stood out and remained at the top in the list of the most used fungicides until today, more effective products have replaced others, and some have been banned. Fungicides of contact generally do not have a specific mode of action, are highly toxic, and when applied to seeds, soil, and plant leaves limit the pathogen survival. The most common are thiram (dithiocarbamate), captan (quinone and heterocyclic), exon (aromatic), and guazatine. Upon entering microbial cells, the molecules promote a series of chemical reactions in nucleic acids and their precursors, and metabolic routes, affecting cell survival [96].

The majority of studies on compatibility have been performed with fungicides and microbial inoculants carrying rhizobia. Fungicides may affect several steps of the symbiosis, from the survival of the rhizobia on the seed to nodule formation and $\mathrm{N}_{2}$ fixation efficiency; in general, studies have been performed with soybean (e.g., [53,97-99]). The use of pesticides intensified in the past two decades, and so did concerns about their compatibility with inoculants [17].

Brikol et al. [21] evaluated the effects of applying different concentrations of the fungicide Thiram (10 to $750 \mu \mathrm{g} \mathrm{mL}^{-1}$ ) on soybean seeds inoculated with B. japonicum, which were grown under greenhouse conditions for 75 days. They observed that concentrations above $100 \mu \mathrm{g} \mathrm{mL}^{-1}$ reduced nodule number and dry weight, as well as the activity of the bacterial enzyme nitrogenase, responsible for the nitrogen fixation process. Similarly, there are reports $[24,100]$ of decrease in soybean nodulation and $\mathrm{N}$ accumulation in plants when seeds were inoculated with B. elkanii (SEMIA 5019) and B. japonicum (SEMIA 5079) and treated with different fungicides, benomyl, captan, carbendazin, carboxin, difenoconazole, thiabendazole, thiram, and tolylfluanid. Changes in nodule number were also observed in a field trial by Zilli et al. [101] when soybean seeds were treated with either carbendazin + thiram or carboxin + thiram.

Interestingly, results of some studies indicate differences between strains in their tolerance to fungicides. For example, in soybean seeds treated with carbendazim + thiram, the lowest tolerance was observed in B. elkanii amongst four soybean Bradyrhizobium strains used in commercial inoculants in Brazil [B. elkanii (SEMIA 5019 and SEMIA 587), B. japonicum (SEMIA 5079), and B. diazoefficiens (SEMIA 5080)] [101]. In another study, Gomes et al. [102] observed no effects on nodulation when seeds were inoculated with B. japonicum SEMIA $5079+$ B. diazoefficiens SEMIA 5080 and treated with carbendazin + thiram. More recently, when the compatibility of B. japonicum SEMIA 5079 and B. elkanii SEMIA 587 was verified with Standak ${ }^{\circledR}$ Top, composed of a mixture of two fungicides and one insecticide (piraclostrobin, thiophanatemethyl, and fipronil), the effects were also more drastic for B. elkanii [25]. Altogether, indications are that B. elkanii is less tolerant to fungicides than B. japonicum or B. diazoefficiens. 
It is reasonable to postulate that the main effects of the fungicides used in seed treatment would be the decrease of rhizobial survival or inhibition of the root infection process, consequently affecting nodulation and BNF, and as a result grain yield, as observed by Zilli et al. [101]. In that study, the grain yield reduced by $20 \%$, in addition to a decrease in the $\mathrm{N}$ content in grains when seeds were treated with B. elkanii SEMIA 587 + carbendazin + thiram (Figure 2). However, some reports have indicated that the effects of fungicides may appear later. For example, in a study by Gomes et al. [102], although fungicides (carbendazin + thiram) did not affect nodulation, plants had lower number of pods per plant, grains per plant, and yield. Intriguingly, in two field experiments performed with soybean in Brazil, seed treatment with Standak ${ }^{\circledR}$ Top affected the total $\mathrm{N}$ accumulated in the grains of plants relying on both BNF and $\mathrm{N}$ fertilizer, indicating the negative impact of the pesticide on $\mathrm{N}$ metabolism [25]. In another study, a decrease in both protein and oleic acid contents was observed in soybean inoculated and treated with mefenoxan + fludioxonil [103].

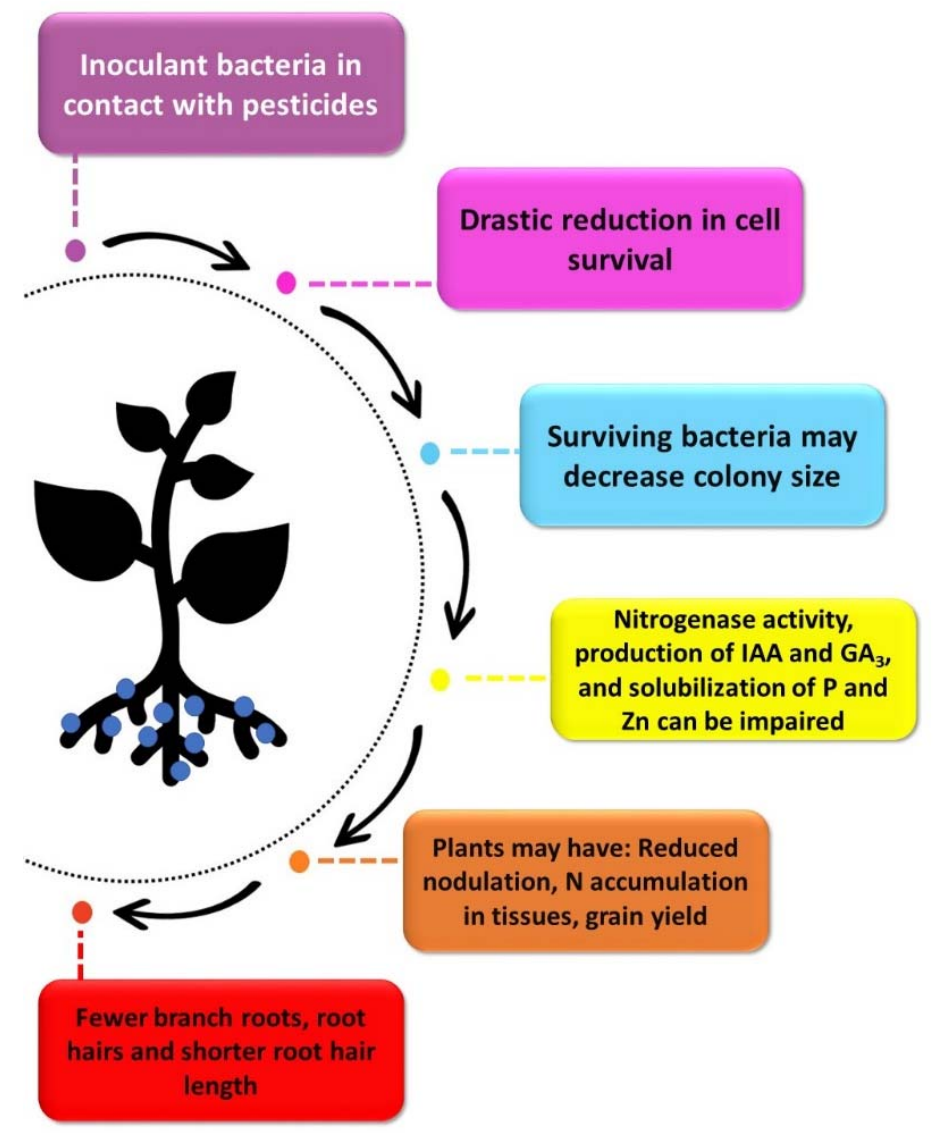

Figure 2. Representation of the effects reported on the incompatibility between pesticides and inoculants, from the moment of contact with microbial cells to the damage to plant development.

As mentioned previously, negative effects may be related to the toxicity of fungicides on microbial cells, followed by impacts on microbial metabolism, reducing the effectiveness of the inoculant. Ahmed et al. [104] evaluated the growth of Bradyrhizobium sp. and Rhizobium sp. in Petri dishes containing solid culture medium and different concentrations of fungicides (captan, thiram, luxan, milcurb, and frernasan-D), soaked in discs placed on the medium. The bacteria were tolerant to concentrations below $100 \mu \mathrm{g} \mathrm{L}^{-1}$, but at $1000 \mu \mathrm{g} \mathrm{L}^{-1}$ inhibition of growth and a decrease in the colony diameter of the surviving cells were observed (Figure 2). Rathjen et al. [105] also reported that Rhizobium leguminosarum bv. viciae (WSM1455) was sensitive to the fungicides Thiram 600 and P-Pickel T (PPT), and their active ingredients (thiram and thiabendazole) at concentrations above $200 \mu \mathrm{g} \mathrm{disc}^{-1}$, with growth halos greater than $10 \mathrm{~mm}$ around the disks containing the fungicide. 
To verify the survival of B. elkanii (SEMIA 5019) and B. japonicum (SEMIA 5079) on seeds treated with fungicides, Campo et al. [24] recovered and counted living cells from seeds inoculated and treated with benomyl, captan, carbendazin, carboxin, difenoconazole, thiabendazole, thiram, or tolylfluanid. After only $2 \mathrm{~h}$ of contact with carbendazin + thiram, viable bacterial cells were reduced by up to $64 \%$, and reached $83 \%$ after $24 \mathrm{~h}$ (Table 1 ). Mortality was verified with all other fungicides, reaching $95 \%$ with the mixture of thiabendazole and tolylfluanid after $24 \mathrm{~h}$ of contact. In addition to rhizobia, fungicides can also impair the contribution of other PGPB. The toxic effect of the combination of carbendazin + thiram was also verified for $A$. brasilense strains $\mathrm{Ab}-\mathrm{V} 5$ and $\mathrm{Ab}-\mathrm{V} 6$ by Santos et al. [27]. In that study, a decrease in the recovery of viable cells from seeds only after $2 \mathrm{~h}$ of contact was observed, and the viable cell count drastically decreased after $24 \mathrm{~h}$, in comparison with the seeds not treated with fungicides (Figure 2).

Table 1. Effect of pesticides on cell viability and/or morphology and on the metabolism of microorganisms used as inoculants.

\begin{tabular}{|c|c|c|c|c|}
\hline Pesticide & Concentration & Microorganism & Effect & Reference \\
\hline $\begin{array}{l}\text { Monocrotophos }{ }^{\mathrm{i}}, \\
\text { Malathion }{ }^{\mathrm{i}}, \text { Chlorpyripho } \\
{ }^{\mathrm{i}} \text {, Dichlorvos }{ }^{\mathrm{i}} \text {, Lindano }{ }^{\mathrm{i}} \mathrm{e} \\
\text { Endosulphan }^{\mathrm{i}}\end{array}$ & $\begin{array}{l}\text { Recommended dose of } \\
\text { each product }\end{array}$ & \multirow[t]{2}{*}{$\begin{array}{l}\text { Gluconacetobacter } \\
\text { diazotrophicus }\end{array}$} & $\begin{array}{l}\text { With the exception of } \\
\text { Malathion, all insecticides } \\
\text { reduced cell viability. } \\
\text { Nitrogenase activity was } \\
\text { totally inhibited by } \\
\text { Monocrotophos, Dichlorvos } \\
\text { and Lindano. Production of } \\
\text { IAA and } \mathrm{GA}_{3} \text {, and } \\
\text { solubilization of P and } \mathrm{Zn} \\
\text { were impaired }\end{array}$ & \multirow[t]{2}{*}{ [106] } \\
\hline $\begin{array}{l}\text { Butachlor }{ }^{h}, \text { Alachlor } \\
\text { Atrazine }^{h} \\
\text { and 2,4-D } \\
\end{array}$ & $\begin{array}{l}\text { Recommended dose of } \\
\text { each product }\end{array}$ & & $\begin{array}{l}\text { Cell growth was hindered by } \\
\text { 2,4-D. All herbicides reduced } \\
\text { the activity of nitrogenase, } \\
\text { the production of IAA and } \\
\text { GA }_{3} \text {, and the solubilization } \\
\text { of } P \text { and } \mathrm{Zn}\end{array}$ & \\
\hline $\begin{array}{l}\text { Captan }{ }^{\mathrm{f}}, \text { Thiram }^{\mathrm{f}}, \text { Luxan }^{\mathrm{f}} \\
\text { and Fernasan-D }\end{array}$ & $1000 \mu \mathrm{g} \mathrm{L}^{-1}$ & $\begin{array}{l}\text { Bradyrhizobium sp. } \\
\text { and Rhizobium sp. }\end{array}$ & $\begin{array}{l}\text { Decreased colony diameter } \\
\text { and inhibited growth in } \\
\text { areas close to the fungicide } \\
\text { application site }\end{array}$ & [104] \\
\hline
\end{tabular}

\begin{tabular}{|c|c|c|c|c|}
\hline $\begin{array}{c}\text { Benomyl }{ }^{\mathrm{f}}, \text { Captan }^{\mathrm{f}}, \\
\text { Carbendazin }{ }^{\mathrm{f}}, \text { Carboxin }^{\mathrm{f}} \text {, } \\
\text { Difenoconazole }^{\mathrm{f}}, \\
\text { Thiabendazole }^{\mathrm{f}}, \text { Thiram }^{\mathrm{f}} \text {, } \\
\text { Tolylfluanid }^{\mathrm{f}}\end{array}$ & $\begin{array}{l}\text { Recommended dose for } \\
\text { soybean }\end{array}$ & $\begin{array}{l}\text { B. elkanii and } B \text {. } \\
\text { japonicum }\end{array}$ & $\begin{array}{l}\text { All fungicides caused } \\
\text { mortality of microorganisms }\end{array}$ & [24] \\
\hline $\begin{array}{c}\text { Imidacloprid }{ }^{\mathrm{i}}, \text { Fipronil }^{\mathrm{i}} \text {, } \\
\text { Thiamethoxam }{ }^{\mathrm{i}}, \\
\text { Endosulphan }{ }^{\mathrm{i}} \mathrm{e} \\
\text { Carbofuran }^{\mathrm{i}}\end{array}$ & $\begin{array}{c}250 \mathrm{~g} \mathrm{ha}^{-1}, 400 \mathrm{~g} \mathrm{ha}^{-1} \\
480 \mathrm{~g} \mathrm{ha}^{-1}, 2.800 \mathrm{~g} \\
\mathrm{ha}^{-1}, 1.650 \mathrm{~g} \mathrm{ha}^{-1} \\
\text { respectively }\end{array}$ & $\begin{array}{l}\text { Herbaspirillum } \\
\text { seropedicae }\end{array}$ & $\begin{array}{l}\text { Endosulphan increased the } \\
\text { lag phase. Carbofuran } \\
\text { increased generation time } \\
\text { and reduced lag phase }\end{array}$ & [107] \\
\hline $\begin{array}{l}\text { Pyraclostrobin }{ }^{\mathrm{f}}, \\
\text { thiophanato-methyl }^{\mathrm{f}} \mathrm{e} \\
\text { fipronil }^{\mathrm{i}}\end{array}$ & $2 \mathrm{~mL} \mathrm{~kg}^{-1}$ maize seed & \multirow{3}{*}{$\begin{array}{l}\text { A. brasilense (strains } \\
\text { Ab-V5 and Ab-V6) }\end{array}$} & $\begin{array}{c}\text { Drastic reduction in cell } \\
\text { concentration } 24 \mathrm{~h} \text { after } \\
\text { inoculation in treated seeds }\end{array}$ & [26] \\
\hline Carbendazin $^{\mathrm{f}}+$ Thiram $^{\mathrm{f}}$ & $\begin{array}{l}40-60 \mathrm{~mL} 20 \mathrm{~kg}^{-1} \\
\text { maize seed }\end{array}$ & & $\begin{array}{c}\text { Drastic reduction in cell } \\
\text { concentration } 24 \mathrm{~h} \text { after } \\
\text { inoculation in treated seeds }\end{array}$ & [27] \\
\hline $\begin{array}{l}\text { metalaxil-m + fludioxonil + } \\
\text { tiametoxame + abamectin }\end{array}$ & $\begin{array}{l}\text { Recommended dose for } \\
\text { maize }\end{array}$ & & $\begin{array}{c}\text { Drastic reduction in cell } \\
\text { concentration } 12 \mathrm{~h} \text { after } \\
\text { inoculation in treated seeds }\end{array}$ & [28] \\
\hline
\end{tabular}


Table 1. Cont.

\begin{tabular}{|c|c|c|c|c|}
\hline Pesticide & Concentration & Microorganism & Effect & Reference \\
\hline $\begin{array}{c}\text { Thiram }^{\mathrm{f}} \text {, Thiram }+ \\
\text { Thiabendazole }^{\mathrm{f}} \text { and PPT }\end{array}$ & $>200 \mu \mathrm{g} \mathrm{L}^{-1}$ & \multirow{2}{*}{$\begin{array}{c}\text { Rhizobium } \\
\text { leguminosarum bv. } \\
\text { viciae }\end{array}$} & $\begin{array}{l}\text { Formation of growth } \\
\text { inhibition halos greater than } \\
10 \mathrm{~mm} \text { around the fungicide }\end{array}$ & \multirow[t]{2}{*}{ [105] } \\
\hline Imidacloprid $^{\mathrm{i}}$ & $0,100,200$ e $300 \mu \mathrm{g} \mathrm{L}^{-1}$ & & $\begin{array}{c}\text { Formation of growth } \\
\text { inhibition halos greater than } \\
10 \mathrm{~mm} \text { around the insecticide } \\
\text { for all concentrations } \\
\text { evaluated }\end{array}$ & \\
\hline $\begin{array}{l}\text { Pyraclostrobin }{ }^{\mathrm{f}}, \\
\text { thiophanato-methyl }^{\mathrm{f}} \mathrm{e} \\
\text { fipronil }^{\mathrm{i}}\end{array}$ & $\begin{array}{l}\text { Recommended dose for } \\
\text { soybean }\end{array}$ & $\begin{array}{l}\text { B. elkanii and } B . \\
\text { japonicum }\end{array}$ & $\begin{array}{l}\text { Drastic decrease in cell } \\
\text { concentration after } 7 \text { days of } \\
\text { exposure. Colony formation } \\
\text { with smaller diameter }\end{array}$ & $\begin{array}{c}\text { Rodrigues et al. } \\
{[25]}\end{array}$ \\
\hline
\end{tabular}

${ }^{\mathrm{f}}$ fungicide, ${ }^{\mathrm{i}}$ insecticide, ${ }^{\mathrm{h}}$ herbicide.

\subsection{Compatibility with Insecticides}

Many herbivorous insects feed on plants during their larval and adult stages, and/or some are important vectors of plant diseases. In both cases, insects may cause serious damages to crops. Insecticides, usually synthetic chemicals, acting as ovicidal, larvicidal, and adulticidal agents are used to prevent growth or kill insects [108]. Neonicotinoids, organophosphates, diamides, pyrethroids, and carbamates act on nerves and muscles; phosphides, cyanides, and carboxamides on respiration, and cyclic ketoenols and ecdysone are agonists that interfere with insect growth and development [109].

Rathjen et al. [105] evaluated the in vitro toxicity of an imidacloprid-based insecticide on R. leguminosarum bv. viciae (WSM1455), and Mesorhizobium ciceri (CC1192). The strains were applied on solid culture medium in Petri dishes and sterile filter discs containing different concentrations $\left(0,100,200\right.$, and $\left.300 \mu \mathrm{g} \mathrm{discs}{ }^{-1}\right)$ of the insecticide. The inhibition of $R$. leguminosarum growth was observed at all concentrations. In alfalfa (Medicago sativa L.), Fox et al. [22] reported that seed treatment with the insecticides methyl parathion, DDT and pentachlorophenol affected the symbiosis with Ensifer (syn. Sinorhizobium) meliloti. The insecticides not only reduced nodule number and dry weight but also nitrogenase activity in nodules and plant biomass production. Ahemad [23] also reported several negative effects with the application of pyriproxifene, at the recommended dose of $1300 \mu \mathrm{g} \mathrm{kg}^{-1}$ soil, in chickpeas (Cicer arietinum L.), peas (Pisum sativum L.), mung beans (Vigna radiata $\mathrm{L}$. Wiclzek), and lentils (Lens esculentus, = Lens culinaris Medik) grown in pots that remained in an open field. Although the plants had not been inoculated, inferring that nodulation was related to indigenous rhizobia, pyriproxifer resulted in a $44 \%$ decrease in nodule number in peas, $14 \%$ in mung beans, and $5 \%$ in chickpeas and lentils, resulting in decreases in nodule dry weight compared with the controls not treated with insecticide. There was also a $17 \%$ decrease in the concentration of nitrogen in the roots of chickpeas, $15 \%$ in peas, $14 \%$ in mung beans, and $18 \%$ in lentils, and a $5 \%$ decrease in the protein contents in grains of chickpeas, $4 \%$ in mung beans, $3 \%$ in lentils, and $1 \%$ in peas, compared with the controls not treated with insecticide.

Insecticides also affect PGPB other than rhizobia. For example, Fernandes et al. [107] studied the effects of five insecticides (imidacloprid, fipronil, fenamethoxam, endosulfan, and carbofuran) indicated for sugarcane (Saccharum spp.) on the diazotrophic bacterium Herbaspirillum seropedicae. In vitro evaluations of cell growth after $33 \mathrm{~h}$ indicated that the insecticides that most interfered with bacterial growth were endosulfan and carbofuran. Madhaiyan et al. [106] evaluated the effect of different insecticides (monocrotophos, malathion, chlorpyriphos, diclorvos, lindane and endosulfan) on Gluconacetobacter diazotrophicus, another PGPB found in association with sugarcane. Except for malathion, all other insecticides reduced cell concentration, and lindane lysed the cells (Figure 2). In the same study, nitrogenase activity was fully inhibited by monocrotophos, dichlorvos, and lindane, $83.3 \%$ by chlorpyriphos, $80.9 \%$ 
by melation, and $33.4 \%$ by endosulfan. Concerning the synthesis of indoleacetic acid (IAA) and gibberellin $\mathrm{A} 3$ (GA3) by G. diazotrophicus, inhibition was observed with lindane, with decreases of $93.2 \%$ and $96.5 \%$ for IAA and $\mathrm{GA}_{3}$, respectively. The authors also described that the insecticides dichlorvos, chlorpyriphos, and lindane completely inhibited the solubilization of phosphate (P) and zinc (Zn) [106] (Figure 2).

\subsection{Compatibility with Herbicides}

Another class of important pesticides for agriculture are herbicides used for weed control. Herbicides have different degrees of specificity based on differences in biochemical pathways in certain plant groups. The mode of action of herbicides has specific degrees of toxicity, depending on the biochemical differences of the plants, and is generally related to the cell division process [110]. Souza and Guedes [110] gathered studies on the action of several herbicides on Allium cepa and Vicia faba plants used as bioindicators, and described how most of these studies reported that herbicides induced both a decrease in the mitotic index, and the occurrence of mitotic chromosomal aberrations.

Examples of herbicides applied worldwide include glyphosate, paraquat, and diuron. Among these, the most well-known is glyphosate; since its introduction in the 1970s, its use spread quickly, facilitated cropping, but also implied in the growing appearance of resistant weeds, resulting from a natural process of plant adaptation, and decreasing its efficacy [111-113]. An important alternative to minimize this problem, in addition to integration with other control methods, would be diversification in the use of herbicides, including others with different mechanisms of action [114].

Few studies have investigated the compatibility between herbicides and inoculants. Madhaiyan et al. [106] evaluated the effects of different herbicides (butachlor, alachlor, atrazine, and 2,4-D) in liquid culture medium on the growth and metabolism of G. diazotrophicus. Cell growth was impaired only in the presence of 2,4-D, but all herbicides reduced nitrogenase activity, the production of IAA and $\mathrm{GA}_{3}$, and the solubilization of $\mathrm{P}$ and $\mathrm{Zn}$. The highest inhibition of nitrogenase activity $(73.6 \%$ and $65.3 \%)$ was observed with alachlor and atrazine, respectively, while butachlor mostly affected production of IAA (53.3\%), whereas 2.4-D mostly affected the production of $\mathrm{GA}_{3}$ (78.8\%). Butachlor was also responsible for the strongest reduction in the solubilization of $\mathrm{P}$ and $\mathrm{Zn}$. Therefore, although herbicides do not affect cell survival, they significantly affect metabolism of G. diazotrophicus [106].

In an assay performed under greenhouse conditions, Angelini et al. [115] evaluated the effects of imazetapir, imazapic, S-metachlor, diclosulam, and glyphosate on diazotrophic bacteria in the soil during the cultivation of peanuts (Arachis hypogaea L.). The seeds were sown and the herbicide was sprayed on the soil surface. All herbicides caused reduction in cell concentration in both free and symbiotic diazotrophic bacteria, and this negative impact was confirmed under field conditions even one year after the application. Nitrogenase activity also reduced due to herbicides, except for glyphosate [115] (Table 2).

The ability of cyanobacteria to fix atmospheric nitrogen in flooded soils suitable for rice cultivation make this group an important ally in maintaining soil fertility and contributing to cereal yield. Thus, Dash et al. [116] evaluated the responses of cyanobacteria in rice plantation soil to the exposure of different agrochemicals, including the herbicide benthiocarb that was applied in one dose at the time of puddling. The herbicide decreased cell growth, which was even worse when combined with urea (used as a fertilizer). Benthiocarb reduced nitrogenase activity by between $13-27 \%$, compared with the control without herbicide, and its combination with urea resulted in an even greater reduction in addition to a decrease in the nitrogen accumulation that reached $47 \%$ at 60 days. 
Table 2. Effect of pesticides on the development of plants the seeds of which had been inoculated.

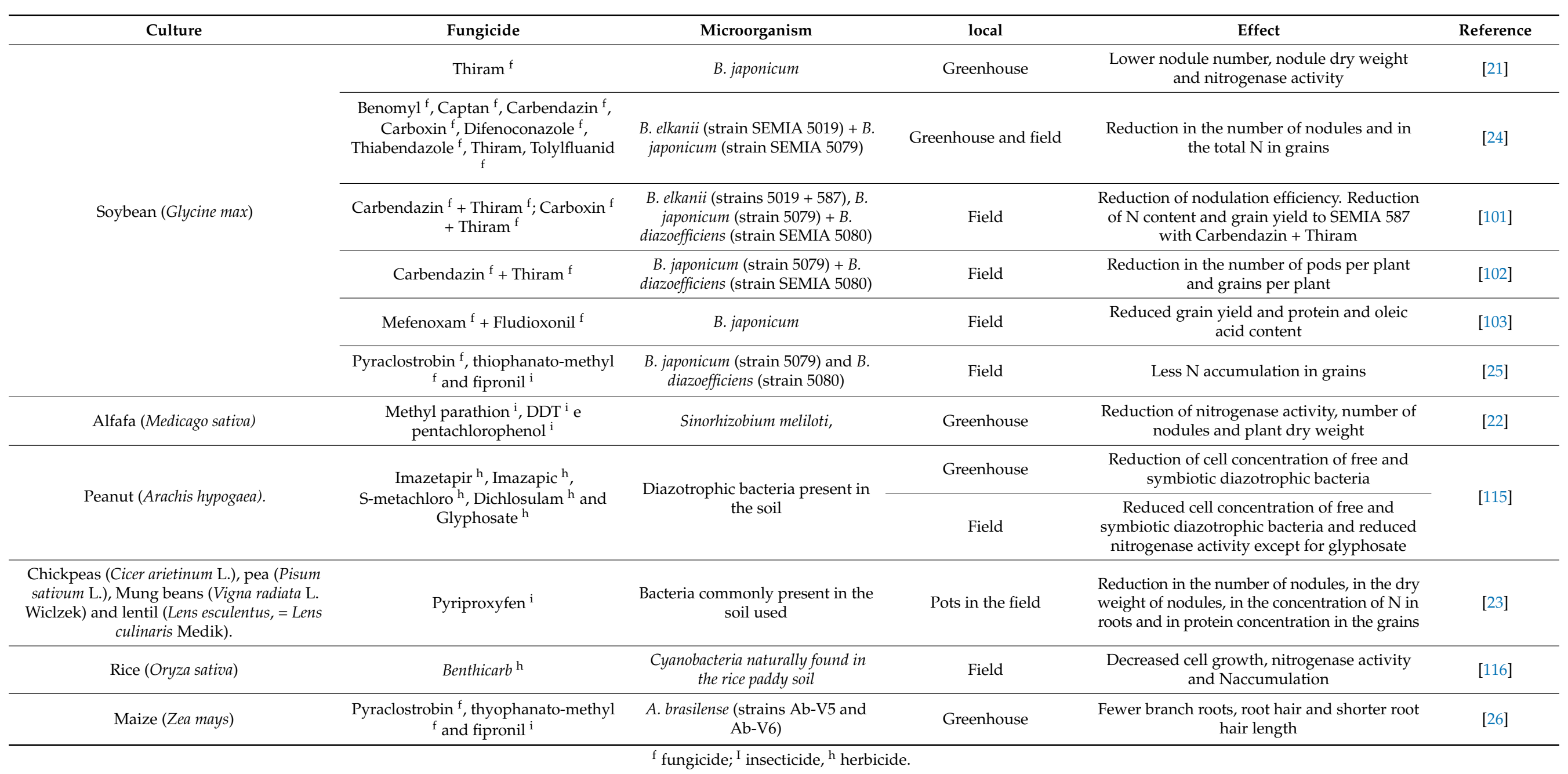


Concerning the symbiosis between legumes and rhizobia, in general, herbicides have been considered less toxic than fungicides and insecticides [100], with glyphosate being the one with lower toxicity $[117,118]$. Although the negative effects of glyphosate on $B$. japonicum growth were reported by King et al. [119], the doses in the experiment were far higher than those recommended for field application. With the release of genetically modified (GM) genotypes tolerant of herbicides, studies on the compatibility with the GM genotypes and herbicides have begun. In soybean, which represents the most used herbicide-tolerant species, glyphosate-resistant (Roundup Ready) pairs of nearly isogenic cultivars were evaluated in six field sites in Brazil for three crop seasons. Although the transgenic trait negatively affected some BNF variables, these effects had no significant impact on soybean grain yield, and no consistent differences between glyphosate and conventional herbicide application were observed on BNF-associated parameters [120]. Similar results were reported in 20 field trials performed with soybean with the ahas transgene, imidazolinone, and conventional herbicides [121]. However, it is worth mentioning that with the increasing doses of the herbicides, BNF can be reduced, especially under abiotic stressing conditions, as shown for glyphosate in soybean [122,123]. Interestingly, it has been long shown that several members of the family Rhizobiaceae were able to degrade glyphosate [124], ability that has been few explored, but that it can contribute to decrease the toxicity effects. Indeed, the search for indigenous and engineered microorganisms, used as isolated microbial species or microbial consortia can result in the complete mineralization of herbicides such as atrazine [125].

\subsection{Compatibility with Mixtures (Fungicides, Insecticides, and Herbicides)}

Approximately $70 \%$ of the pesticides available in the market contain mixtures of two or more types of fungicides and insecticides [126] and are often combined with herbicides at the time of application, aiming to facilitate the combined control of pests, diseases, and weeds. However, the damage to microbial inoculants increases with the number of combined chemicals. As previously mentioned, Standak ${ }^{\circledR}$ Top, one of the most used for treatments of seeds in several countries, especially for soybean, is composed of two fungicides and one insecticide; it affects the survival of B. japonicum and, especially, B. elkanii cells, with a drastic decrease verified after 7 days of contact [25]. It is worth mentioning that pre-inoculated soybean seeds have been in contact with Standak ${ }^{\circledR}$ Top for up to 90 days, often resulting in zero recoveries of rhizobial cells from seeds [126].

Another interesting observation in the study by Rodrigues et al. [25] was the changes in colony morphology, smaller with the increase of the exposure to the pesticide. However, regular colonies were recovered after the bacteria were grown under optimal conditions, indicating an adaptive mechanism to the stressful conditions when exposed to the pesticides.

Santos et al. [26] evaluated the compatibility of Standak ${ }^{\circledR}$ Top with A. brasilense strains $\mathrm{Ab}-\mathrm{V} 5$ and $\mathrm{Ab}-\mathrm{V} 6$. First, differences were observed between strains, with lower tolerance of $\mathrm{Ab}-\mathrm{V} 5$, so that after $24 \mathrm{~h}$ of exposure the recovery of viable cells dropped from $4.56 \times 10^{5}$ to $4.37 \times 10^{2}$ cells seed $^{-1}$. In a greenhouse experiment with the combined strains, Standak ${ }^{\circledR}$ Top decreased the number of lateral roots and root hairs and resulted in shorter root hair length.

Pereira et al. [28] also reported the mortality of A. brasilense strains Ab-V5 and AbV6 in maize seeds treated with a mixture of fungicides and insecticides (metalaxyl-M + fludioxonil + thiamethoxam + abamectin). The cell survival rate after $12 \mathrm{~h}$ of inoculation of seeds treated with the pesticide was only $13.56 \%$, whereas in untreated seeds it was $65.87 \%$.

\section{Are There Alternatives to the Challenges of Using Pesticides and Microbial Inoculants?}

Remarkable advances in genetic engineering have occurred particularly in the last decade and are advancing towards obtaining plant genotypes resistant to abiotic stresses, pests and diseases [127-129]. However, large-scale agriculture to feed the increasingly growing population still demands the use of pesticides for at least the next two decades. Practical agriculture without pesticides may be a dream for most of society, but it is currently restricted to a few farmers, most in small properties, and there is no technology in the 
research pipeline to make it feasible for the majority of the cropped areas in a short time. On the other hand, the use of bioproducts aimed at the total or partial replacement of chemicals used for the control of pests, diseases, weeds, and fertilizers is growing at a rate never seen before [17]. The major limitation, as we have shown in this review, is the low compatibility between pesticides and microbial inoculants applied to seeds. Therefore, there is an urgent need to develop alternatives to make microbial inoculants compatible with pesticides, and mainly to develop more biopesticides and other eco-friendly techniques to control pests and diseases. However, the compatibility of bioproducts must also be investigated, as not all microorganisms are compatible.

Ahemad and Khan [130] selected strains of R. leguminosarum that were tolerant to high concentrations of the insecticides fipronil and pyriproxifene used in peas. The tolerant strain MRP1 was characterized as the highest in the synthesis of IAA, siderophores, and exopolysaccharides (EPS); in a field trial performed in soil previously treated with insecticides, the strain contributed to the significant increases in nodulation, $\mathrm{N}$ and $\mathrm{P}$ contents of roots and shoots, and grain yield. The results show the feasibility of selecting strains tolerant of pesticides. One main limitation is the increasing number of pesticides used in agriculture, which would require multiple steps of microbial selection.

To develop pesticides less harmful to microbial bioinoculants, the inclusion of carriers for the active ingredients might be simpler than obtaining tolerant strains. Unfortunately, the pesticide industry has not demonstrated interest in following this strategy, probably because the chemical industry is financially more powerful than the inoculant industry and the limited interest in investing in less toxic molecules.

Another strategy could be to take advantage of microbial metabolites instead of living microbes [87]; however, this is only applicable to microorganisms that produce secondary metabolites useful to the host plants, such as Azospirillum sp. in grasses and pastures, and not by mechanisms that require living microorganisms, such as rhizobia to nodulate legumes.

Investment should be made in innovation in formulations, including cell protection to minimize or avoid the toxic effects of pesticides on microbial cells. The addition of protective molecules such as polymers, chemicals, or synthesized by microorganisms may help in this regard, for example, polyhydroxyburytate (PHB) [50,131,132] and biofilms [133].

In Brazil, with no short-term solutions for compatibility in sight, the only feasible strategy is physically avoiding the contact of inoculants with pesticides. Seed treatment with pesticides, for example, for soybeans that currently may contact up to 14 chemical products, an in-furrow application of biologicals has proven to be effective in guaranteeing the benefits to the crop. Despite the need for increasing the dose of inoculant applied in-furrow, the cost of inoculant is low in comparison with the benefits. A pioneering study confirming that the in-furrow inoculation of soybean with 2.5 times the concentration used for seed inoculation alleviated the effects of seed treatment with agrochemicals was published in 2010 [56]. Despite requiring that the farmers buy new equipment, $20 \%$ of the farmers in Brazil adopted this technique by 2020. Other strategies, with an emphasis on soil-spray and leaf-spray inoculation $[57,86,134,135]$ have also been investigated and show some degree of effectiveness, but are not as effective as in-furrow and seed inoculations.

\section{Final Remarks}

The critical analysis of this review points to some certainties: (i) considering the technologies available today and those that should be available in coming years, large-scale agriculture to meet the increasing food demand will require pesticides; (ii) the demand for higher sustainability in agriculture, with bioproducts aiming at partially or fully replacing pesticides and fertilizers is increasing; (iii) inoculants or biofertilizers have been increasingly adopted by farmers, but their compatibility with pesticides, especially when used for seed treatment, is low; (iv) strategies to solve the incompatibility between pesticides and inoculants are needed, as those proposed until now are still very modest with regards to their feasibility; (v) the development of more biopesticides and other eco-friendly techniques to control pests and diseases and compatible with inoculants is needed. 
Incompatibility between pesticides and inoculants affects cell survival and metabolism. The level of incompatibility with the pesticides depends on the active principle, formulation, doses, time of contact with the cells, and may vary with the bacterial species or strain. Despite the increasing market for biological products aiming at more sustainable agriculture [136], very few intellectual and economic investments have been made to search for compatibility of biological products with chemicals. Therefore, there is an urgent need to emphasize studies and development of innovative strategies to mitigate the incompatibility between pesticides and microbial inoculants.

Author Contributions: The writing, investigation and formal analysis were led by M.S.S. with support from T.F.R., M.H. and M.A.N. Regarding methodology and supervision, the authors contributed equally. M.H. led the validation and resources. All authors have read and agreed to the published version of the manuscript.

Funding: National Institute of Science and Technology, INCT-Plant-Growth Promoting Microorganisms for Agricultural Sustainability and Environmental Responsibility (CNPq 465133/2014-4, Fundação Araucária-STI 043/2019, CAPES) and Embrapa (20.19.02.009.00.01).

Data Availability Statement: All data and materials cited in the manuscript are freely available for the scientific community.

Acknowledgments: M.S.S. acknowledges a PhD fellowship from Araucaria Foundation of support to the Scientific and Technological Development of the State of Paraná. M.A. Nogueira and M. Hungria are research fellows of CNPq. We also thank the financial support given by the National Institute of Science and Technology, INCT-Plant-Growth Promoting Microorganisms for Agricultural Sustainability and Environmental Responsibility.

Conflicts of Interest: Authors declare no competing interest regarding the data or the manuscript.

\section{References}

1. United Nations, Department of Economic and Social Affairs, Population Division. World Population Prospects 2019 Highlights. Available online: https:/ / population.un.org/wpp/Publications/Files/WPP2019_Highlights.pdf (accessed on 4 January 2021).

2. Ameen, A.; Raza, S. Green Revolution: A Review. Int. J. Adv. Sci. Res. 2018, 3, 129-137. [CrossRef]

3. Armanda, D.T.; Guinée, J.B.; Tukker, A. The second green revolution: Innovative urban agriculture's contribution to food security and sustainability-A review. Glob. Food Secur. 2019, 22, 13-24. [CrossRef]

4. Arora, N.K. Agricultural sustainability and food security. Environ. Sustain. 2018, 1, 217-219. [CrossRef]

5. Arora, N.K.; Fatima, T.; Mishra, I.; Verma, S. Microbe-based Inoculants: Role in Next Green Revolution. In Environmental Concerns and Sustainable Development; Metzler, J.B., Ed.; Springer Singapore: Singapore, 2019; Volume 1, pp. 191-246.

6. Harwood, J. Could the adverse consequences of the green revolution have been foreseen? How experts responded to unwelcome evidence. Agroecol. Sustain. Food Syst. 2019, 44, 509-535. [CrossRef]

7. Singh, Z.; Kaur, J.; Kaur, R.; Hundal, S.S. Toxic Effects of Organochlorine Pesticides: A Review. Am. J. Biosci. 2016, 4, 11. [CrossRef]

8. Arora, N.K.; Tewari, S.; Singh, S.; Lal, N.; Maheshwari, D.K. PGPR for Protection of Plant Health Under Saline Conditions. In Bacteria in Agrobiology: Stress Management; Metzler, J.B., Ed.; Springer Singapore: Singapore, 2011; pp. $239-258$.

9. Tilman, D.; Cassman, K.G.; Matson, P.A.; Naylor, R.; Polasky, S. Agricultural sustainability and intensive production practices. Nature 2002, 418, 671-677. [CrossRef]

10. Foley, J.A.; Ramankutty, N.; Brauman, K.A.; Cassidy, E.S.; Gerber, J.S.; Johnston, M.; Mueller, N.D.; O'Connell, C.; Ray, D.K.; West, P.C.; et al. Solutions for a cultivated planet. Nature 2011, 478, 337-342. [CrossRef]

11. Hungria, M.; Nogueira, M.A. Microrganismos e a sustentabilidade de sistemas agrícolas de alta produtividade. In FertBio 2016; SBCS: Goiânia, Brazil, 2016; ISBN 978-85-86504-15-0.

12. Hungria, M.; Nogueira, M.A.; Araujo, R.S. Inoculation of Brachiaria spp. with the plant growth-promoting bacterium Azospirillum brasilense: An environment-friendly component in the reclamation of degraded pastures in the tropics. Agric. Ecosyst. Environ. 2016, 221, 125-131. [CrossRef]

13. Llewellyn, D. Does Global Agriculture Need Another Green Revolution? Engineering 2018, 4, 449-451. [CrossRef]

14. Malusá, E.; Vassilev, N. A contribution to set a legal framework for biofertilisers. Appl. Microbiol. Biotechnol. 2014, 98, 6599-6607. [CrossRef]

15. Hungria, M.; Mendes, I.C. Nitrogen Fixation with Soybean: The Perfect Symbiosis? In Biological Nitrogen Fixation; Wiley: Hoboken, NJ, USA, 2015; pp. 1009-1024.

16. Martin-Guay, M.-O.; Paquette, A.; Dupras, J.; Rivest, D. The new Green Revolution: Sustainable intensification of agriculture by intercropping. Sci. Total Environ. 2018, 615, 767-772. [CrossRef] [PubMed] 
17. Santos, M.S.; Nogueira, M.A.; Hungria, M. Microbial inoculants: Reviewing the past, discussing the present and previewing an outstanding future for the use of beneficial bacteria in agriculture. AMB Express 2019, 9, 1-22. [CrossRef]

18. FAOSTAT. 2019. Available online: http://www.fao.org/faostat/en/\#home (accessed on 15 March 2021).

19. Fishel, F.M. Pest Management and Pesticides: A Historical Perspective. Agronomy Department, UF/IFAS Extension, 2016. Available online: http:/ / edis.ifas.ufl.edu (accessed on 16 November 2020).

20. Hungria, M.; Nogueira, M.A.; Campos, L.J.M.; Menna, P.; Brandi, F.; Ramos, Y.G. Seed pre-inoculation with Bradyrhizobium as time-optimizing option for large-scale soybean cropping systems. Agron. J. 2020, 112, 5222-5236. [CrossRef]

21. Anupama, B.; Nidhi, S.; Kiran, S.; Bikrol, A.; Saxena, N.; Singh, K. Response of Glycine max in relation to nitrogen fixation as influenced by fungicide seed treatment. Afr. J. Biotechnol. 2005, 4, 667-671. [CrossRef]

22. Fox, J.E.; Gulledge, J.; Engelhaupt, E.; Burow, M.E.; McLachlan, J.A. Pesticides reduce symbiotic efficiency of nitrogen-fixing rhizobia and host plants. Proc. Natl. Acad. Sci. USA 2007, 104, 10282-10287. [CrossRef] [PubMed]

23. Ahemad, M. Growth suppression of legumes in pyriproxyfen stressed soils: A comparative study. Emir. J. Food Agric. 2014, $26,66-72$. [CrossRef]

24. Campo, R.J.; Araujo, R.S.; Hungria, M. Nitrogen fixation with the soybean crop in Brazil: Compatibility between seed treatment with fungicides and bradyrhizobial inoculants. Symbiosis 2009, 48, 154-163. [CrossRef]

25. Rodrigues, T.F.; Bender, F.R.; Sanzovo, A.W.S.; Ferreira, E.; Nogueira, M.A.; Hungria, M. Impact of pesticides in properties of Bradyrhizobium spp. and in the symbiotic performance with soybean. World J. Microbiol. Biotechnol. 2020, 36, 172. [CrossRef]

26. Santos, M.S.; Rondina, A.B.L.; Nogueira, M.A.; Hungria, M. Compatibility of Azospirillum brasilense with Pesticides Used for Treatment of Maize Seeds. Int. J. Microbiol. 2020, 2020, 1-8. [CrossRef]

27. Santos, M.S.; Rodrigues, T.F.; Ferreira, E.; Megias, M.; Nogueira, M.A.; Hungria, M. Method for Recovering and Counting Viable Cells from Maize Seeds Inoculated with Azospirillum brasilense. J. Pure Appl. Microbiol. 2020, 14, 195-204. [CrossRef]

28. Pereira, L.C.; De Carvalho, C.; Suzukawa, A.K.; Correia, L.V.; Pereira, R.C.; Dos Santos, R.F.; Braccini, A.L.; Osipi, E.A.F. Toxicity of seed-applied pesticides to Azospirillum spp.: An approach based on bacterial count in the maize rhizosphere. Seed Sci. Technol. 2020, 48, 241-246. [CrossRef]

29. Mahmood, I.; Imadi, S.R.; Shazadi, K.; Gul, A.; Hakeem, K.R. Effects of Pesticides on Environment; Springer Science and Business Media LLC: Berlin/Heidelberg, Germany, 2016; pp. 253-269.

30. Abubakar, Y.; Tijjani, H.; Egbuna, C.; Adetunji, C.O.; Kala, S.; Kryeziu, T.L.; Ifemeje, J.C.; Patrick-Iwuanyanwu, K.C. Pesticides, History, and Classification. In Natural Remedies for Pest, Disease and Weed Control; Elsevier BV: Amsterdam, The Netherlands, 2020; pp. 29-42.

31. Costa, L.G.; Galli, C.L.; Murphy, S.D. Toxicology of Pesticides: Experimental, Clinical and Regulatory Aspects, 1st ed.; Springer: Berlin/Heidelberg, Germany, 1987.

32. Carson, R. Silent Spring, 1st ed.; Houghton Mifflin: Boston, MA, USA, 1962; p. 368.

33. Stern, V.M.; Smith, R.F.; Van Der Bosch, R.; Hagen, R.S. The integrated control concept. Hilgardia 1959, 29, 81-101. [CrossRef]

34. Moura, A.P. Manejo Integrado de Pragas: Estratégias e Táticas de Manejo Para o Controle de Insetos e Ácaros-Praga em Hortaliças; Embrapa Hortaliças: Brasília, Brazil, 2015; p. 28.

35. Donley, N. The USA lags behind other agricultural nations in banning harmful pesticides. Environ. Health 2019, 18, 1-12. [CrossRef]

36. Kim, K.-H.; Kabir, E.; Jahan, S.A. Exposure to pesticides and the associated human health effects. Sci. Total Environ. 2017, 575, 525-535. [CrossRef] [PubMed]

37. Sharma, A.; Kumar, V.; Shahzad, B.; Tanveer, M.; Sidhu, G.P.S.; Handa, N.; Kohli, S.K.; Yadav, P.; Bali, A.S.; Parihar, R.D.; et al. Worldwide pesticide usage and its impacts on ecosystem. SN Appl. Sci. 2019, 1, 1446. [CrossRef]

38. Rani, L.; Thapa, K.; Kanojia, N.; Sharma, N.; Singh, S.; Grewal, A.S.; Srivastav, A.L.; Kaushal, J. An extensive review on the consequences of chemical pesticides on human health and environment. J. Clean. Prod. 2021, 283, 124657. [CrossRef]

39. Williams, P.M. Current Use of Legume Inoculant Technology. In Biological Nitrogen Fixation; Metzler, J.B., Ed.; Springer: Berlin/Heidelberg, Germany, 1984; pp. 173-200.

40. Smith, R.S. Legume inoculant formulation and application. Can. J. Microbiol. 1992, 38, 485-492. [CrossRef]

41. Hungria, M.; Campo, R.J. Economical and Environmental Benefits of Inoculation and Biological Nitrogen Fixation with Soybean: Situation in South America. Available online: http:/ /ainfo.cnptia.embrapa.br/digital/bitstream/item/173978/1/ID-23469-pt-1.pdf (accessed on 1 April 2021).

42. Hungria, M.; Campo, R.J.; Mendes, I.C. A Importância do Processo de Fixação Biológica do Nitrogênio para a Cultura da Soja: Componente Essencial Para a Competitividade do Produto Brasileiro; Documentos, 283; Embrapa Soja: Londrina, Brazil, 2007 ; p. 80.

43. Ormeño-Orrillo, E.; Hungria, M.; Martínez-Romero, E. Dinitrogen-fixing prokaryotes. In The Prokaryotes—Prokaryotic Physiology and Biochemistry; Rosemberg, E., De Long, E.F., Lory, S., Stackebrandt, E., Thompson, F., Eds.; Springer: Berlin/Heidelberg, Germany, 2013; pp. 427-451. [CrossRef]

44. Hungria, M.; Campo, R.J.; Souza, E.M.; Pedrosa, F.O. Inoculation with selected strains of Azospirillum brasilense and A. lipoferum improves yields of maize and wheat in Brazil. Plant Soil 2010, 331, 413-425. [CrossRef]

45. Gomes, D.F.; Ormeño-Orrillo, E.; Hungria, M. Biodiversity, symbiotic efficiency and genomics of Rhizobium tropici and related species. In Biological Nnitrogen Fixation; De Bruijn, F.J., Ed.; John Wiley \& Sons, Inc.: Hoboken, NJ, USA, 2015 ; pp. 747-756. 
46. Zhang, Y.J.; Zheng, W.T.; Everall, I.; Young, J.P.W.; Zhang, X.X.; Tian, C.F.; Sui, X.H.; Wang, E.T.; Chen, W.X. Rhizobium anhuiense sp. nov., isolated from effective nodules of Vicia faba and Pisum sativum. Int. J. Syst. Evol. Microbiol. 2015, 65, $2960-2967$. [CrossRef] [PubMed]

47. Mercante, F.M.; Otsubo, A.A.; Brito, O.R. New Native Rhizobia Strains for Inoculation of Common Bean in the Brazilian Savanna. Rev. Bras. Ciência Solo 2017, 41, 1-11. [CrossRef]

48. Pandey, R.P.; Srivastava, A.K.; Gupta, V.K.; O'Donovan, A.; Ramteke, P.W. Enhanced yield of diverse varieties of chickpea (Cicer arietinum L.) by different isolates of Mesorhizobium ciceri. Environ. Sustain. 2018, 1, 425-435. [CrossRef]

49. Daur, I.; Saad, M.M.; Eida, A.A.; Ahmad, S.; Shah, Z.H.; Ihsan, M.Z.; Muhammad, Y.; Sohrab, S.S.; Hirt, H. Boosting Alfalfa (Medicago sativa L.) Production with Rhizobacteria from Various Plants in Saudi Arabia. Front. Microbiol. 2018, 9, 477. [CrossRef] [PubMed]

50. Mariana, S.S.; Mariangela, H.; Marco, A.N.; Santos, M.S.; Hungria, M.; Nogueira, M.A. Production of polyhydroxybutyrate (PHB) and biofilm by Azospirillum brasilense aiming at the development of liquid inoculants with high performance. Afr. J. Biotechnol. 2017, 16, 1855-1862. [CrossRef]

51. Gundi, J.S.; Santos, M.S.; Oliveira, A.L.M.; Nogueira, M.A.; Hungria, M. Development of liquid inoculants for strains of Rhizobium tropici group using response surface methodology. Afr. J. Biotechnol. 2018, 17, 411-421. [CrossRef]

52. Hungria, M.; Andrade, D.D.S.; De O'Chueire, L.M.; Probanza, A.; Guttierrez-Mañero, F.J.; Megías, M. Isolation and characterization of new efficient and competitive bean (Phaseolus vulgaris L.) rhizobia from Brazil. Soil Biol. Biochem. 2000, 32, 1515-1528. [CrossRef]

53. Hungria, M.; Loureiro, M.F.; Mendes, I.C.; Campo, R.J.; Graham, P.H. Inoculant Preparation, Production and Application. In Nitrogen Fixation in Agriculture, Forestry, Ecology, and the Environment; Springer Science and Business Media LLC: Berlin/Heidelberg, Germany, 2005; pp. 223-253.

54. Bashan, Y.; De-Bashan, L.E.; Prabhu, S.R.; Hernandez, J.-P. Advances in plant growth-promoting bacterial inoculant technology: Formulations and practical perspectives (1998-2013). Plant Soil 2014, 378, 1-33. [CrossRef]

55. Cassán, F.; Okon, Y.; Creus, C.M. Handbook for Azospirillum: Technical Issues and Protocols; Springer International Publishing: London, UK, 2015; ISBN 978-3-319-06541-0.

56. Campo, R.J.; Araujo, R.S.; Mostasso, F.L.; Hungria, M. In-furrow inoculation of soybean as alternative to fungicide and micronutrient seed treatment. Rev. Bras. Ciência Solo 2010, 34, 1103-1112. [CrossRef]

57. Fukami, J.; Nogueira, M.A.; Araujo, R.S.; Hungria, M. Accessing inoculation methods of maize and wheat with Azospirillum brasilense. AMB Express 2016, 6, 1-13. [CrossRef]

58. Moretti, L.G.; Lazarini, E.; Bossolani, J.W.; Parente, T.L.; Caioni, S.; Araujo, R.S.; Hungria, M. Can additional inoculations increase soybean nodulation and grain yield? Agron. J. 2018, 110, 715-721. [CrossRef]

59. Drew, E.; Herridge, D.; Ballard, R.; O’hara, G.; Deaker, R.; Denton, M.; Yates, R.; Gemell, G.; Hartley, E.; Phillips, L.; et al. Inoculating Legumes: A Practical Guide, 2nd ed.; Grains Research and Development Corporation: Barton, Australian, $2009 ;$ p. 72. ISBN 978-1-921779-45-9.

60. MAPA-Ministério da Agricultura, Pecuária e Abastecimento. Instrução Normativa No 5, de 6 de Agosto de 2004. Diário Oficial da União da República Federativa do Brasil, 6 August 2004.

61. MAPA-Ministério da Agricultura, Pecuária e Abastecimento. Instrução Normativa No 13, de 24 de Março de 2011. Diário Oficial da União da República Federativa do Brasil, 24 March 2011.

62. Hungria, M.; Campo, R.J. Inoculantes microbianos: Situação no Brasil. In Biofertilizantes en Iberoamérica: Visión Técnica, Científica y Empresarial; Izaguirre-Mayoral, M.L., Labandera, C., Sanjuan, J., Eds.; Cyted/Biofag: Montevideo, Uruguay, 2007 ; pp. 22-31.

63. Herrmann, L.; Lesueur, D. Challenges of formulation and quality of biofertilizers for successful inoculation. Appl. Microbiol. Biotechnol. 2013, 97, 8859-8873. [CrossRef]

64. Deaker, R.; Hartley, E.; Gemell, G.; Herridge, D.F.; Karanja, N. Inoculant production and quality control. In Working with Rhizobia; Howieson, J.G., Dilworth, J.G., Eds.; ACIAR: Canberra, Australia, 2016; pp. 167-186.

65. ANPII, Associação Nacional dos Produtores e Importadores de Inoculantes. Estatísticas. 2020. Available online: http://www. anpii.org.br/estatisticas / (accessed on 22 November 2020).

66. Santos, M.S.; Nogueira, M.A.; Hungria, M. Outstanding impact of Azospirillum brasilense strains Ab-V5 and Ab-V6 on the Brazilian agriculture: Lessons that farmers are receptive to adopt new microbial inoculants. Rev. Bras. Ciência Solo 2021, 45, e0200128. [CrossRef]

67. Hungria, M.; Nogueira, M.A.; Araujo, R.S. Co-inoculation of soybeans and common beans with rhizobia and azospirilla: Strategies to improve sustainability. Biol. Fertil. Soils 2013, 49, 791-801. [CrossRef]

68. Hungria, M.; Nogueira, M.A.; Araujo, R.S. Soybean Seed Co-Inoculation with Bradyrhizobium spp. and Azospirillum brasilense: A New Biotechnological Tool to Improve Yield and Sustainability. Am. J. Plant Sci. 2015, 6, 811-817. [CrossRef]

69. Bashan, Y.; De-Bashan, L.E. How the Plant Growth-Promoting Bacterium Azospirillum Promotes Plant Growth—A Critical Assessment. Adv. Agron. 2010, 108, 77-136. [CrossRef]

70. Cerezini, P.; Kuwano, B.H.; dos Santos, M.B.; Terassi, F.; Hungria, M.; Nogueira, M.A. Strategies to promote early nodulation in soybean under drought. Field Crop. Res. 2016, 196, 160-167. [CrossRef]

71. Mahanty, T.; Bhattacharjee, S.; Goswami, M.; Bhattacharyya, P.; Das, B.; Ghosh, A.; Tribedi, P. Biofertilizers: A potential approach for sustainable agriculture development. Environ. Sci. Pollut. Res. 2016, 24, 3315-3335. [CrossRef] [PubMed] 
72. Fukami, J.; Cerezini, P.; Hungria, M. Azospirillum: Benefits that go far beyond biological nitrogen fixation. AMB Express 2018, 8, 1-12. [CrossRef]

73. Silva, E.R.; Zoz, J.; Oliveira, C.E.S.; Zuffo, A.M.; Steiner, F.; Zoz, T.; Vendruscolo, E.P. Can co-inoculation of Bradyrhizobium and Azospirillum alleviate adverse effects of drought stress on soybean (Glycine max L. Merrill.)? Arch. Microbiol. 2019, 201, 325-335. [CrossRef]

74. Aeron, A.; Khare, E.; Jha, C.K.; Meena, V.S.; Aziz, S.M.A.; Islam, M.T.; Kim, K.; Meena, S.K.; Pattanayak, A.; Rajashekara, H.; et al. Revisiting the plant growth-promoting rhizobacteria: Lessons from the past and objectives for the future. Arch. Microbiol. 2019, 202, 665-676. [CrossRef] [PubMed]

75. Vishwakarma, K.; Kumar, N.; Shandilya, C.; Mohapatra, S.; Bhayana, S.; Varma, A. Revisiting Plant-Microbe Interactions and Microbial Consortia Application for Enhancing Sustainable Agriculture: A Review. Front. Microbiol. 2020, 11, 1-21. [CrossRef] [PubMed]

76. Cassán, F.; López, G.; Nievas, S.; Coniglio, A.; Torres, D.; Donadio, F.; Molina, R.; Mora, V. What Do We Know About the Publications Related with Azospirillum? A Metadata Analysis. Microb. Ecol. 2021, 81, 278-281. [CrossRef] [PubMed]

77. Zhang, J.; Hussain, S.; Zhao, F.; Zhu, L.; Cao, X.; Yu, S.; Jin, Q. Effects of Azospirillum brasilense and Pseudomonas fluorescens on nitrogen transformation and enzyme activity in the rice rhizosphere. J. Soils Sediments 2018, 18, 1453-1465. [CrossRef]

78. Thirumal, G.; Reddy, R.S.; Triveni, S.; Nagaraju, Y.; Prasannakumar, B. Screening of Native Rhizobia and Pseudomonas Strains for Plant Growth Promoting Activities. Int. J. Curr. Microbiol. Appl. Sci. 2017, 6, 616-625. [CrossRef]

79. Sandini, I.E.; Pacentchuk, F.; Hungria, M.; Nogueira, M.A.; Cruz, S.P.; Nakatani, A.S.; Araujo, R.S. Seed inoculation with Pseudomonas fluorescens promotes growth, yield and reduces nitrogen application in maize. Int. J. Agric. Biol. 2019, 22, 1369-1375. [CrossRef]

80. Araujo, F.F.; Guaberto, L.M.; Silva, I.F. Bioprospecção de bactérias promotoras de crescimento em Brachiaria brizantha. Rev. Bras. Zootec. 2012, 41, 521-527. [CrossRef]

81. Ribeiro, V.P.; Marriel, I.E.; De Sousa, S.M.; Lana, U.G.D.P.; Mattos, B.B.; De Oliveira, C.A.; Gomes, E.A. Endophytic Bacillus strains enhance pearl millet growth and nutrient uptake under low-P. Braz. J. Microbiol. 2018, 49, 40-46. [CrossRef]

82. O'Callaghan, M. Microbial inoculation of seed for improved crop performance: Issues and opportunities. Appl. Microbiol. Biotechnol. 2016, 100, 5729-5746. [CrossRef]

83. Nogueira, M.A.; Prando, A.M.; Oliveira, A.B.; Lima, D.; Conte, O.; Harger, N.; Oliveira, F.T.; Hungria, M. Ações de Transferência de Tecnologia em Inoculação/Coinoculação com Bradyrhizobium e Azospirillum na Cultura da Soja na Safra 2017/18 no Estado do Paraná; Embrapa Soja: Londrina, Brazil, 2018; p. 15.

84. de Souza, J.E.B.; Ferreira, E.P.D.B. Improving sustainability of common bean production systems by co-inoculating rhizobia and azospirilla. Agric. Ecosyst. Environ. 2017, 237, 250-257. [CrossRef]

85. Reis, V.M. Uso de Bactérias Fixadores de Nitrogênio Como Inoculante Para Aplicação em Gramineas; Embrapa Agrobiologia: Seropédica, Brazil, 2007; p. 22.

86. Galindo, F.S.; Filho, M.C.M.T.; Buzetti, S.; Rodrigues, W.L.; Santini, J.M.K.; Alves, C.J. Nitrogen fertilisation efficiency and wheat grain yield affected by nitrogen doses and sources associated with Azospirillum brasilense. Acta Agric. Scand. Sect. B Plant Soil Sci. 2019, 69, 606-617. [CrossRef]

87. Fukami, J.; Ollero, F.J.; Megías, M.; Hungria, M. Phytohormones and induction of plant-stress tolerance and defense genes by seed and foliar inoculation with Azospirillum brasilense cells and metabolites promote maize growth. AMB Express 2017, 7, 1-13. [CrossRef]

88. Pereg, L.; De-Bashan, L.E.; Bashan, Y. Assessment of affinity and specificity of Azospirillum for plants. Plant Soil 2016, 399, 389-414. [CrossRef]

89. Racca, R.; González, N. Nutrición nitrogenada de la alfalfa e impacto de la fijación simbiótica del nitrógeno. In El Cultivo de la Alfalfa en la Argentina; Gasigalup, D.H., Ed.; Ediciones INTA: Buenos Aires, Argentina, 2007; pp. 69-79.

90. Buntić, A.V.; Stajković-Srbinović, O.S.; Knežević, M.M.; Kuzmanović, Đ.Ž.; Rasulić, N.V.; Delić, D.I. Development of liquid rhizobial inoculants and pre-inoculation of alfalfa seeds. Arch. Biol. Sci. 2019, 71, 379-387. [CrossRef]

91. Leite, R.C.; Santos, A.C.; Dos Santos, J.G.D.; Leite, R.C.; Oliveira, L.B.T.; Hungria, M. Mitigation of mombasa grass (Me-gathyrsus maximus) dependence on nitrogen fertilization as a function of inoculation with Azospirillum brasilense. Rev. Bras. Ciên. Solo. 2019, 43, 180-234. [CrossRef]

92. Heinrichs, R.; Universidade Estadual Paulista; Meirelles, G.C.; Santos, L.F.D.M.; Lira, M.V.D.S.; Lapaz, A.D.M.; Nogueira, M.A.; Bonini, C.D.S.B.; Filho, C.V.S.; Moreira, A.; et al. Azospirillum inoculation of 'Marandu' palisade grass seeds: Effects on forage production and nutritional status. Semin. Ciências Agrárias 2020, 41, 465-478. [CrossRef]

93. Steinfeld, H.; Gerber, P.; Wassenaar, T.; Castel, V.; Rosales, M.; De Haan, C. Livestock's Long Shadow: Environmental Issues and Options, 1st ed.; United Nations Food and Agriculture Organization: Rome, Italy, 2006.

94. Fonte, S.J.; Nesper, M.; Hegglin, D.; Velásquez, J.E.; Ramirez, B.; Rao, I.M.; Bernasconi, S.M.; Bünemann, E.K.; Frossard, E.; Oberson, A. Pasture degradation impacts soil phosphorus storage via changes to aggregate-associated soil organic matter in highly weathered tropical soils. Soil Biol. Biochem. 2014, 68, 150-157. [CrossRef]

95. Braccini, A.; Mariucci, G.; Suzukawa, A.; Lima, L.; Piccinin, G. Co-inoculação e Modos de Aplicação de Bradyrhizobium japonicum e Azospirillum brasilense e Adubação Nitrogenada na Nodulação das Plantas e Rendimento da Cultura da Soja. Sci. Agrar. Parana. 2016, 15, 27-35. [CrossRef] 
96. Garcia, A. Fungicidas I: Utilização no Controle Químico de Doenças e sua Ação contra os Fitopatógenos; Embrapa Rondônia: Porto Velho, Brazil, 1999; p. 34.

97. Curley, R.L.; Burton, J.C. Compatibility of Rhizobium japonicum with Chemical Seed Protectants 1. Agron. J. 1975, 67, 807-808. [CrossRef]

98. Leterme, P.; Revellin, C.; Catroux, G. Effect of some fungicide seed treatments on the survival of Bradyrhizobium japonicum and on the nodulation and yield of soybean [Glycine max. (L) Merr.]. Biol. Fertil. Soils 1993, 16, 211-214. [CrossRef]

99. Cattelan, A.J.; Hungria, M. Nitrogen nutrition and inoculation. In Tropical Soybean, Improvement and Production; FAO, Plant Production and Protection Series, No. 27; Embrapa-CNPSo: Londrina, Brazil, 1994; pp. 201-215.

100. Campo, R.J.; Hungria, M. Compatibilidade de Uso de Inoculantes e Fungicidas no Tratamento de Sementes de Soja; Embrapa Soja: Londrina, Brazil, 2000; p. 31.

101. Zilli, J.É.; Ribeiro, K.G.; Campo, R.J.; Hungria, M. Influence of fungicide seed treatment on soybean nodulation and grain yield. Rev. Bras. Ciência Solo 2009, 33, 917-923. [CrossRef]

102. Gomes, Y.C.B.; Valadão, F.C.D.A.; Dalchiavon, F.C. Joint use of fungicides, insecticides and inoculants in the treatment of soybean seeds. Rev. Ceres 2017, 64, 258-265. [CrossRef]

103. Schulz, T.J.; Thelen, K.D. Soybean Seed Inoculant and Fungicidal Seed Treatment Effects on Soybean. Crop. Sci. 2008, 48, 1975-1983. [CrossRef]

104. Ahmed, T.H.M.; Elsheikh, E.A.E.; Mahdi, A.A. The in vitro compatibility of some Rhizobium and Bradyrhizobium strains with fungicides. Afr. Crop. Sci. Conf. Proc. 2007, 8, 1171-1178. [CrossRef]

105. Rathjen, J.; Ryder, M.; Riley, I.; Lai, T.; Denton, M. Impact of seed-applied pesticides on rhizobial survival and legume nodulation. J. Appl. Microbiol. 2020, 129, 389-399. [CrossRef] [PubMed]

106. Madhaiyan, M.; Poonguzhali, S.; Hári, K.; Saravanan, V.; Sa, T. Influence of pesticides on the growth rate and plant-growth promoting traits of Gluconacetobacter diazotrophicus. Pestic. Biochem. Physiol. 2006, 84, 143-154. [CrossRef]

107. Fernandes, M.F.; Procópio, S.D.O.; Teles, D.A.; Filho, J.G.D.S.; Filho, A.C.; Machado, T.N. Toxicidade de inseticidas utilizados na cultura da cana-de-açúcar à bactéria diazotrófica Herbaspirillum seropedicae. Rev. Ciências Agrar. Amaz. J. Agric. Environ. Sci. 2012, 55, 318-326. [CrossRef]

108. Insecticidal efficacy of lichens and their metabolites-A mini review. J. Appl. Pharm. Sci. 2018, 8, 159-164. [CrossRef]

109. Nauen, R.; Slater, R.; Sparks, T.C.; Elbert, A.; McCaffery, A. IRAC: Insecticide Resistance and Mode-of-action Classification of Insecticides. In Modern Crop Protection Compounds; Wiley: Weinheim, Germany, 2019; pp. 995-1012.

110. De Souza, C.P.; Guedes, T.D.A.; Fontanetti, C.S. Evaluation of herbicides action on plant bioindicators by genetic biomarkers: A review. Environ. Monit. Assess. 2016, 188, 694. [CrossRef]

111. Martinez, D.A.; Loening, U.E.; Graham, M.C. Impacts of glyphosate-based herbicides on disease resistance and health of crops: A review. Environ. Sci. Eur. 2018, 30, 1-14. [CrossRef]

112. Barros, V.M.D.S.; Pedrosa, J.L.F.; Gonçalves, D.R.; De Medeiros, F.C.L.; Carvalho, G.R.; Gonçalves, A.H.; Teixeira, P.V.V.Q. Herbicides of biological origin: A review. J. Hortic. Sci. Biotechnol. 2020, 1-9. [CrossRef]

113. Wilms, W.; Woźniak-Karczewska, M.; Syguda, A.; Niemczak, M.; Ławniczak, Ł.; Pernak, J.; Rogers, R.D.; Chrzanowski, L. Herbicidal ionic liquids-A promising future for old herbicides? Review on synthesis, toxicity, biodegradation and efficacy studies. J. Agric. Food Chem. 2020, 68, 10456-10488. [CrossRef]

114. Adegas, F.S.; Vergas, L.; Gazziero, D.L.P.; Karam, D. Impacto Econômico da Resistência de Plantas Daninhas a Herbicidas no Brasil; Embrapa Soja: Londrina, Brazil, 2017; p. 12.

115. Angelini, J.; Silvina, G.; Taurian, T.; Ibáñez, F.; Tonelli, M.L.; Valetti, L.; Anzuay, M.S.; Ludueña, L.; Muñoz, V.; Fabra, A. The effects of pesticides on bacterial nitrogen fixers in peanut-growing area. Arch. Microbiol. 2013, 195, 683-692. [CrossRef] [PubMed]

116. Dash, N.P.; Kumar, A.; Kaushik, M.S.; Abraham, G.; Singh, P.K. Agrochemicals influencing nitrogenase, biomass of N2-fixing cyanobacteria and yield of rice in wetland cultivation. Biocatal. Agric. Biotechnol. 2017, 9, 28-34. [CrossRef]

117. Procópio, S.O.; Santos, J.B.; Jacques, R.J.S.; Kasuya, M.C.M.; Silva, A.A.; Werlang, R.C. crescimento de estirpes de Bradyrhizobium sob influência dos herbicidas glyphosate potássico, fomesafen, imazethapyr e carfentrazone-ethyl. Rev. Ceres. 2004, 51, 179-188

118. Drouin, P.; Sellami, M.; Prévost, D.; Fortin, J.; Antoun, H. Tolerance to agricultural pesticides of strains belonging to four genera ofRhizobiaceae. J. Environ. Sci. Health Part B 2010, 45, 757-765. [CrossRef] [PubMed]

119. King, C.; Purcell, L.C.; Vories, E.D. Plant Growth and Nitrogenase Activity of Glyphosate-Tolerant Soybean in Response to Foliar Glyphosate Applications. Agron. J. 2001, 93, 179-186. [CrossRef]

120. Hungria, M.; Mendes, I.C.; Nakatani, A.S.; Dos Reis-Junior, F.B.; Morais, J.Z.; De Oliveira, M.C.N.; Fernandes, M.F. Effects of the glyphosate-resistance gene and herbicides on soybean: Field trials monitoring biological nitrogen fixation and yield. Field Crop. Res. 2014, 158, 43-54. [CrossRef]

121. Hungria, M.; Nakatani, A.S.; Souza, R.A.; Sei, F.B.; Chueire, L.M.D.O.; Arias, C.A. Impact of the ahas transgene for herbicides resistance on biological nitrogen fixation and yield of soybean. Transgenic Res. 2014, 24, 155-165. [CrossRef]

122. Zablotowicz, R.M.; Reddy, K.N. Nitrogenase activity, nitrogen content, and yield responses to glyphosate in glyphosate-resistant soybean. Crop. Prot. 2007, 26, 370-376. [CrossRef]

123. Zobiole, L.H.; Kremer, R.J.; Oliveira, R.S.; Constantin, J. Glyphosate affects chlorophyll, nodulation and nutrient accumulation of "second generation" glyphosate-resistant soybean (Glycine max L.). Pestic. Biochem. Physiol. 2011, 99, 53-60. [CrossRef] 
124. Liu, C.-M.; McLean, P.A.; Sookdeo, C.C.; Cannon, F.C. Degradation of the Herbicide Glyphosate by Members of the Family Rhizobiaceae. Appl. Environ. Microbiol. 1991, 57, 1799-1804. [CrossRef]

125. Sene, L.; Converti, A.; Secchi, G.A.R.; Simão, R.D.C.G. New aspects on atrazine biodegradation. Braz. Arch. Biol. Technol. 2010, 53, 487-496. [CrossRef]

126. Hungria, M.; Nogueira, M.A. Tecnologias de inoculação da cultura da soja: Mitos, verdades e desafios. In Boletim de Pesquisa 2019/2020; Fundação MT: Rondonópolis, Brazil, 2019; pp. 50-62.

127. Mourgues, F.; Brisset, M.-N.; Chevreau, E. Strategies to improve plant resistance to bacterial diseases through genetic engineering. Trends Biotechnol. 1998, 16, 203-210. [CrossRef]

128. Molinari, S. Natural genetic and induced plant resistance, as a control strategy to plant-parasitic nematodes alternative to pesticides. Plant Cell Rep. 2010, 30, 311-323. [CrossRef] [PubMed]

129. Zhang, Y.; Lubberstedt, T.; Xu, M. The Genetic and Molecular Basis of Plant Resistance to Pathogens. J. Genet. Genom. 2013, 40, 23-35. [CrossRef] [PubMed]

130. Ahemad, M.; Khan, M.S. Comparative toxicity of selected insecticides to pea plants and growth promotion in response to insecticide-tolerant and plant growth promoting Rhizobium leguminosarum. Crop. Prot. 2010, 29, 325-329. [CrossRef]

131. Kadouri, D.; Jurkevitch, E.; Okon, Y. Involvement of the Reserve Material Poly- $\beta$-Hydroxybutyrate in Azospirillum brasilense Stress Endurance and Root Colonization. Appl. Environ. Microbiol. 2003, 69, 3244-3250. [CrossRef]

132. Bhat, S.G.; Subin, R.S. Bacterial polyhydroxyalkanoates production and its applications. In Microbial Bioproducts; Bhat, S.G., Nambisan, P., Eds.; Directorate of Public Relation and Publication: Kerala, India, 2015; pp. 70-96.

133. Fukami, J.; Abrantes, J.L.F.; Del Cerro, P.; Nogueira, M.A.; Ollero, F.J.; Megias, M.; Hungria, M. Revealing strategies of quorum sensing in Azospirillum brasilense strains Ab-V5 and Ab-V6. Arch. Microbiol. 2017, 200, 47-56. [CrossRef] [PubMed]

134. Mariangela, H.; Marco, A.N.; Ricardo, S.A. Alternative methods of soybean inoculation to overcome adverse conditions at sowing. Afr. J. Agric. Res. 2015, 10, 2329-2338. [CrossRef]

135. Correia, L.V.; Felber, P.H.; Pereira, L.C.; Braccini, A.L.; Carvalho, D.U.; Da Cruz, M.A.; Matera, T.C.; Santos, R.F.; Marteli, D.C.V.; Osipi, E.A.F. Inoculation of Wheat with Azospirillum spp.: A Comparison Between Foliar and In-furrow Applications. J. Agric. Sci. $2019,12,194$. [CrossRef]

136. DunhamTrimmer ${ }^{\circledR}$ Global Biocontrol Market Overview. Trends, Drivers \& Insights, 2019. DunhamTrimmer ${ }^{\circledR}$, Florida-USA. Available online: http://dunhamtrimmer.com/wp-content/uploads/2019/05/TOCDT_Global_Biocontrol_Overview_Links.pdf (accessed on 2 February 2021). 